\title{
Exercise and Shark Liver Oil Supplementation Reduce Tumor Growth and Cancer Cachexia in Walker 256 Tumor Bearing Rats
}

Marcelo Kryczyk ${ }^{1}$, Jaisson Bordignon ${ }^{2}$, Fabiola lagher ${ }^{1}$, Everson Araujo Nunes ${ }^{1}$, Ricardo Key Yamazaki ${ }^{1}$, Gleisson Alisson Perreira de Brito', Juliano Machado ${ }^{1}$, Katya Naliwaiko ${ }^{1}$, Aldre IP Tanhoffer ${ }^{1}$, Ricardo A Tanhoffer ${ }^{1}$ and Luiz Cláudio Fernandes ${ }^{1 *}$

${ }^{1}$ Laboratory of Cell Metabolism, Department of Physiology, Biological Science Building, Federal University of Paraná, Curitiba-PR, Brazil ${ }^{2}$ Biological and Health Sciences, West of Santa Catarina University, Videira-SC, Brazil

\begin{abstract}
This study investigated whether exercise associated to shark liver oil supplementation ( $1 \mathrm{~g} / \mathrm{kg} \mathrm{b.w./day)} \mathrm{affects}$ tumor growth, cachexia, lipid peroxidation and proteins expression involved in cell death in Walker 256 tumorbearing rats. Animals were divided into 4 groups: sedentary tumor-bearing $(W)$, sedentary tumor-bearing shark liver oil supplemented (WSL), exercised tumor-bearing (EW) and exercised tumor-bearing shark liver oil supplemented (EWSL). Training sessions consisted of 6 bouts, 30 seconds each with $50 \%$ body-weight load attached to the trunk followed by 1 minute of resting (jump training). Five minutes after the finish jump training the exercise groups were subjected to 30 minutes of continuous swimming with a load equivalent to $6 \%$ of body weight, 4 times a week during 8 weeks. Tumor cells were injected at the $6^{\text {th }}$ training week and all groups were killed 15 days post inoculation. Tumor weight $(\mathrm{g})$ in W group was of $26.50 \pm 1.79$ and in the WSL, EW and EWSL was of $14.08 \pm$ $0.91,15.60 \pm 0.55$ and $12.60 \pm 1.07$, respectively. The group $\mathrm{W}$ showed hypoglycemia $(68.67 \pm 2.12 \mathrm{mg} / \mathrm{dl})$, hyperlactacidemia $(1.49 \pm 0.06 \mathrm{mmol} / \mathrm{L})$, hypertriacylglycerolemia $(161.4 \pm 9.4 \mathrm{mg} / \mathrm{dl})$ and body weight reduction $(13.21 \pm 2.25 \mathrm{~g})$ characterizing cachexia state. The groups WSL, EW and EWSL presented reduction of tumor cells proliferation ex vivo, and the production of hydroperoxide and apoptosis was increased. Bax/Bcl-2 expression ratio was increased only in the exercised groups. Shark liver oil supplementation and exercise alone were able in to avoid the installation of cachexia state and also reduced tumor growth, but the association of both cause further effect only in the tumor growth.
\end{abstract}

Keywords: Exercise; Cancer cachexia; Shark liver oil; Lipid peroxidation; Apoptosis

\section{Introduction}

Several studies have examined the role of exercise as an adjunct therapy in cancer treatment. It has been reported that exercise changes tumor progression $[1,2]$ as well as improves wellbeing and quality of life of cancer patients $[3,4]$. These changes in tumor progression appear to be related to a process called lipid peroxidation (LP). Gago-Dominguez et al. [5] proposed that LP represents a protective mechanism in breast cancer, and reviewed the evidence of the role of this process on established reproductive, hormonal, and non-hormonal factors for breast cancer. Exercise increases oxygen consumption levels considerably by as much as more than 10 -fold regarding to resting level. This will lead to an increase of reactive oxygen species (ROS) production [6].

LP is one of the most investigated features of ROS actions on membrane structure and function. It has been shown that lipid hydroperoxides and oxygenated products of LP degradation as well as lipid peroxidation initiators (e.g.: ROS) participate in many process such as signal transduction cascades [7], cell proliferation control, induction of differentiation, maturation, and apoptosis [8]. It has been shown that LP and ROS are triggers and essential mediators of apoptosis, which eliminates precancerous and cancerous, virusinfected and damaged cells that threaten our health [9].

Shark liver oil (SLO) is an ancient remedy among the fishermen who live along the west coast of Norway and Sweden. It was not until the early part of the last century that biochemists discovered substances in this oil that may account for its traditional use namely, alkylglycerols [10]. Alkylglycerols are glyceryl ether lipids that are structurally characterized by an ether linkage of a fatty acid attached to the chain length and by the number of double bonds; several derivatives of the ether lipid have been identified [11]. Alkylglycerols inhibit the growth of primary tumors and the metastasis of Lewis lung carcinoma growing in $\mathrm{C} 57 \mathrm{Bl} / 6$ mice [12]. It has been reported a time-and concentrationdependent development of oxidative stress when sensitive HL-60 cells were exposed to membrane-targeted ether lipids [13]. Oxidative stress has been suggested as an inducer of apoptosis in human leukemic cells [14]. Induction of oxidative stress followed by apoptosis is also assumed to explain the inhibition of L-1 sarcoma-induced angiogenesis by alkylglycerols [15].

SLO supplementation as well as exercise has been used for cancer chemoprevention and also treatment. So far we are not aware of any study about the association of both exercise and SLO supplementation on cancer growth, cachexia, proliferation and death of tumor cells. Therefore, this study investigated whether exercise associated to shark liver oil supplementation ( $1 \mathrm{~g} / \mathrm{kg}$ b.w./day) affects tumor growth, cachexia, lipid peroxidation and proteins expression involved in cell death in Walker 256 tumor-bearing rats. We hypothesize that both interventions might be beneficial for tumor-bearing individuals.

*Corresponding author: Luiz Cláudio Fernandes, Laboratory of Cell Metabolism Department of Physiology, Federal University of Parana, Brazil, Tel: (55) (41) 33611647; Fax: (55) (41) 3361-1714; E-mail: Icfer@ufpr.br

Received February 19, 2014; Accepted March 17, 2014; Published March 20 , 2014

Citation: Kryczyk M, Bordignon J, lagher F, Nunes EA, Yamazaki RK, et al. (2014) Exercise and Shark Liver Oil Supplementation Reduce Tumor Growth and Cancer Cachexia in Walker 256 Tumor Bearing Rats. J Cancer Sci Ther 6: 087-093. doi:10.4172/1948-5956.1000254

Copyright: (C) 2014 Kryczyk M, et al. This is an open-access article distributed under the terms of the Creative Commons Attribution License, which permits unrestricted use, distribution, and reproduction in any medium, provided the original author and source are credited. 


\section{Materials and Methods}

\section{Chemical and enzymes}

All chemicals and enzymes were purchased from Sigma Chemical (St. Louis, MO), unless otherwise indicated.

\section{Study design}

All proceeds involving animals were approved by the Animal Ethics Committee of the Biological Science Building, Federal University of Paraná under number 293. Wistar rats (70 days old) were obtained from the animal house and maintained under controlled temperature $23^{\circ} \mathrm{C}$ and $12 \mathrm{~h} \mathrm{light} / 12 \mathrm{~h}$ dark cycle, with free access to water and a standard commercial chow food (Nutrilab - CR1, Nuvital Nutrients Ltda, Curitiba-PR, Brazil).

Rats were randomized to one of the four experimental groups: sedentary tumor-bearing (W), sedentary tumor-bearing SLO supplemented (WSL), exercised tumor-bearing (EW) and exercised tumor-bearing SLO supplemented (EWSL). Training sessions was carried out in a swimming pool apparatus, in which water temperature was maintained between $29^{\circ} \mathrm{C}$ and $32^{\circ} \mathrm{C}$. The apparatus is composed of 12 individual swimming pools in which each rat swims individually. The depth of the water column is maintained at $50 \mathrm{~cm}$. The exercise training protocol consisted of six 30-s sets, each followed by 1 min of rest, with a load equivalent to $50 \%$ of body weight load attached to the back, 4 times a week for 8 weeks. Rats were acclimated to the water environment for 2 days before the exercise protocol was initiated. So that they could further adapt to the water environment, rats underwent progressive training, beginning with a load corresponding to $30 \%$ of their body weight and reaching $50 \%$ at the eighth exercise session. Because the load is too great for the rats to stay above the water surface by swimming, they must perform serial jumps to keep breathing. In $30 \mathrm{~s}$, the duration of each set, a rat performs 10 jumps, on average. This training protocol is characterized by power and anaerobic exercise [16]. Five minutes after the finish jump training the exercise groups were subjected to 30 minute of continuous swimming with a load equivalent to $6 \%$ of body weight, 4 times a week during 8 weeks. This training protocol is characterized aerobic exercise. Training sessions were performed on Mondays, Tuesdays, Thursdays, and Fridays; all trained rats rested on the other days.

Supplemented rats received SLO at a level of $1 \mathrm{~g}$ per $\mathrm{kg}$ body weight per day, during the whole 8 weeks experiment period, always after exercise session as a single daily bolus by using a micropipette. The SLO (Ecomer) was kindly donated by Naturalis Nutrição e Farma Ltda. At the $6^{\text {th }}$ week of supplementation tumor cells were subcutaneously inoculated in the tumor groups in the right flank with a sterile suspension of $3 \times 10^{7}$ Walker 256 tumor cells, obtained from a rat where cells grew in the peritoneal cavity. Fifteen days after tumor inoculation the animals were killed by decapitation using a guillotine. Body weight was regularly measured during experimental period and tumor weight was determined at sacrifice. Blood was collected and serum prepared to measure the concentrations of glucose, lactate and triacylglycerol. Tumor tissue also was removed for studies. All groups were killed $48 \mathrm{~h}$ after the last session of exercise in order to eliminate any acute effects of the exercise on metabolic parameters.

\section{Blood metabolite measurements}

Serum glucose was determined by using a glucose oxidase-based assay kit [17] and quantified in a spectrophotometer (Ultrospec 2000, Pharmacia Biotech) by measuring the absorbance at $505 \mathrm{~nm}$.
Triacylglycerol (TAG) concentration was measured using an assay kit as described elsewhere [18]. Lactate was assayed enzimatically. For this procedure, serum $(0.5 \mathrm{ml})$ was added to $0.1 \mathrm{ml}$ of perchloric acid $(25 \%)$ and left for 10 minutes at $4{ }^{\circ} \mathrm{C}$, followed by a centrifugation at $3000 \mathrm{x}$ $g$ for $5 \mathrm{~min}$. The supernatant was collected and neutralized with Tris/ $\mathrm{KOH}(2 \mathrm{M} / 0.5 \mathrm{M})$, incubated with the assay buffer for $40 \mathrm{~min}$ and the lactate concentration was determined by measuring the absorbance at $340 \mathrm{~nm}$ [19].

\section{Walker 256 tumor cells proliferation ex vivo}

This was performed according to Nunes et al. [20]. At sacrifice whole tumor was removed and chopped with a scalpel into a flask containing saline $0.9 \%$. The cells suspension was obtained by filtration through a funnel with gauze. Red blood cells were discharged by means of a solution containing $\mathrm{NH}_{4} \mathrm{Cl}(15.5 \mathrm{mM})$ and EDTA (5.5 $\mathrm{mM}$ ) in a proportion 9:1, respectively. Tumor cells were prepared by centrifugation at $1000 \mathrm{~g}$ for $5 \mathrm{~min}$ and were resuspended in RPMI 1640 medium. Then, tumor cells were cultured in RPMI 1640 medium enriched with $10 \%$ fetal calf serum containing $100 \mathrm{U} / \mathrm{ml}$ penicillin, 100 $\mathrm{mg} / \mathrm{ml}$ streptomycin and $0.05 \mu \mathrm{Ci}$ of $\left[2-\mathrm{C}^{14}\right]$-thymidine. Cells $\left(10^{5}\right.$ cells/ $\mathrm{ml}$ ) were seeded in 96 well microplates and after $48 \mathrm{~h}$ of culture at $37^{\circ} \mathrm{C}$ in $5 \% \mathrm{CO}_{2}$; they were harvested onto glass fiber disks and washed using a Skatron cell harvester. Radioactive thymidine incorporation into DNA was determined in a Beckman LS 6000IC scintillation counter. Each cell preparation was cultured in sixtuplicate and the data are express in counts per minute (cpm). At the final preparation of cells they were $97 \%$ viable.

\section{Lipid peroxidation products}

Lipid peroxidation was measured as described by Nouroozzadeh et al. [21]. This method is based on the oxidation of hydroperoxide iron to ferric iron which is bound to xylenol orange. Walker 256 tumor cells (200g) were homogenized in $1 \mathrm{ml}$ of methanol and centrifuged to 5000 $\mathrm{x} \mathrm{g}$ for 5 minutes to $4^{\circ} \mathrm{C}$. For each sample, of $90 \mu \mathrm{l}$ of supernatant were put on 6 centrifuge tubes. Three tubes were added with $10 \mu$ of TPP (triphenylphosphine) solution $10 \mathrm{mM}$, diluted in methanol, which is a selective for reduction by hydroperoxides and in others only $10 \mu \mathrm{l}$ methanol. Tubes were incubated at room temperature for 30 minutes. At the end of incubation, $900 \mu \mathrm{l}$ of the reagent FOX2 $(100 \mu \mathrm{M}$ xylenol orange, butylated hydroxytoluene $400 \mathrm{mM}, 25 \mathrm{mM}$ sulfuric acid and ammonium ferrous sulphate $250 \mathrm{mM}$ in methanol 90\%) was added to each tube and incubated again at room temperature for 30 minutes. The reading was held in spectrophotometer at $560 \mathrm{~nm}$.

The concentration of hydroperoxide in the samples was determinate by subtracting the absorbance of the samples without TPP with the absorbance of samples treated with TPP. The value obtained was then interpolated in the standard curve of hydrogen peroxide, which was obtained with standard solutions of hydrogen peroxide in different concentrations $(100.0,50.0,25.0,12.5,6.2,3.1$ and $1.6 \mu \mathrm{M})$. The concentration of hydroperoxide $(\mathrm{nmol} / \mathrm{ml})$ was corrected by protein concentration $(\mathrm{mg} / \mathrm{ml})$ which was measured by Bradford's method [22].

\section{Apoptosis}

The percentage of tumor cells undergoing apoptosis was evaluated using annexin V-FITC (Pharmingen, SanvDiego, CA, USA). Cells were stained with annexin V-FITC $30 \mathrm{~min} 4^{\circ} \mathrm{C}$ in the dark. The fluorescence was analyzed using flow cytometry; the positive cells were considered to be in an early stage of apoptosis. 
Citation: Kryczyk M, Bordignon J, lagher F, Nunes EA, Yamazaki RK, et al. (2014) Exercise and Shark Liver Oil Supplementation Reduce Tumor Growth and Cancer Cachexia in Walker 256 Tumor Bearing Rats. J Cancer Sci Ther 6: 087-093. doi:10.4172/1948-5956.1000254

\section{Western blot analysis of Bax, Bcl-2 and NF-kB (p65, p52 and ІкВ)}

Protein content in tumor extract was determined by Bradford's method [22], to normalize the amount of protein in different samples $(60 \mu \mathrm{g} / \mathrm{lane})$. Pieces of accurately weighed tumor tissue $(0.1 \mathrm{~g})$ were homogenized in lysis buffer $(0.7 \mathrm{ml})$ containing $100 \mathrm{mM}$ Trizma Base, $\mathrm{pH}$ 7.5, 10 mM EDTA, 10\% sodium dodecyl sulfate (SDS), 10 $\mathrm{mM}$ sodium pyrophosphate, $10 \mathrm{mM}$ sodium fluoride $10 \mathrm{mM}$ sodium orthovanadate and $10 \mu \mathrm{g} / \mathrm{ml}$ aprotinin. Then, the samples were boiled for $5 \mathrm{~min}$ and subjected to SDS polyacrylamide gel electrophoresis (15\% polyacrylamide) followed by electrophoretic transfer onto nitrocellulose membranes (Hybond-ECL; Amershan Bioscience, São Paulo, Brazil) using a semi-dry blotter apparatus (HOEFER-Mini VE; Amersham Biosciences). The membranes were incubated overnight with goat polyclonal IgG anti-Bax antibody, goat polyclonal IgG antiBcl-2, goat polyclonal IgG anti-p65 antibody, goat polyclonal IgG anti-p52 antibody and goat polyclonal IgG anti-ІкB, at dilution of 1:500 they were then incubated with a secondary antibody-conjugated rabbit horseradish peroxidase diluted to 1:2000. Protein load control was done with anti-total $\beta$-Actin (1:500), in the same membranes after antibody stripping. Finally, the membranes were subjected to enhanced chemiluminescence (Super Signal Systems Pierce). Blots were scanned using Image J software to detect relative band intensities.

\section{Determination of fatty acids content by HPLC and alkylglycerol by GC-MS}

The lipids were extracted as previously described [23] from SLO and standard commercial chow. The lipids were saponified using $2 \mathrm{ml}$ of an alkaline methanol solution ( $1 \mathrm{~mol} \mathrm{NaOH} / \mathrm{l}$ in $90 \%$ methanol) at $37^{\circ} \mathrm{C}$, for $2 \mathrm{~h}$, in a shaking water bath. Then, the alkaline solution was acidified to $\mathrm{pH} 3$ with $\mathrm{HCl}$ solution $(1 \mathrm{~mol} / \mathrm{l})$. Fatty acids were then extracted three times with $2 \mathrm{ml}$ hexane. After the extraction procedure and saponification [24-26] the fatty acids were derivatized with 4-bromomethyl-7 methoxycoumarim [27], and the analysis performed on a Varian model LC-10A liquid chromatography. The samples were placed on a C8 column $(25 \mathrm{~cm} \times 4.6 \mathrm{~mm}$ i.d., $5 \mu \mathrm{m}$ of particles $)$, with a flow rate of $1 \mathrm{ml} / \mathrm{min}$ of acetonitrile/water (77:23, vol/vol), and a fluorescence detector ( $325 \mathrm{~nm}$ excitation and $395 \mathrm{~nm}$ emission). The standard mixture of fatty acids was obtained from Sigma Chemical Co. (St. Louis, MO). The elution sequence and limit of detection were determined. The minimum limit of quantification of the fatty acids ranged from 1 to $10 \mathrm{ng}$. One curve of calibration for each standard, determining coefficients of correlation and regression, was obtained. Alkylglycerol profile was determined by GC-MS.

Total lipids were extracted from SLO capsules (Ecomer") using chloroform-methanol (2:1 vol/vol) according to Folch et al. [23] and Vitorino et al. [28]. Then the content was hydrolyzed and kept under $100^{\circ} \mathrm{C}$ for $2 \mathrm{~h}$. the samples were dried out under gas nitrogen and added $0.2 \mathrm{ml}$ of ethanoyl ethanoate and $0.2 \mathrm{ml}$ of pyridine followed by $30 \mathrm{~min}$ incubation at $100^{\circ} \mathrm{C}$ [29]. Alkyglycerols were separated on a GC-MS Saturn using a CP-Sil-\% CB Chrom-pack column $(30 \mathrm{~m}$ x $0.25 \mathrm{~mm})$ (Table 1).

\section{Statistical analysis}

Data are presented as mean \pm standard error mean (SEM). Statistical analysis was performed by two-way analysis of variance (two-way ANOVA) by using supplementation and exercise as factors. To test for differences between groups the post hoc Bonferroni's test was applied. The value of $\mathrm{p}<0.05$ was taken to indicate statistical significance.

\section{Results}

Fatty acids profile of regular chow and SLO are showed in Table 2A. Regular chow is rich in linoleic acid (omega-6), which constitutes $50 \%$ of total fatty acids, oleic $(18 \%)$ and palmitic acid $(25 \%)$. Very low quantities of $a$-linolenic acid (omega-3) were detected, and long chain polyunsaturated fatty acids eicosapentaenoic acid (EPA) and docosahexaenoic acid (DHA) were not detected. In contrast, SLO presented about $18 \%$ of omega- 3 fatty acids family. Palmitic and oleic acids were the most abundant components in this oil, $32 \%$ and $28 \%$ respectively. Alkylglycerol profile is shown in Table $2 \mathrm{~B}$. Regular chow has no presence of alkylglycerol whatsoever. In the capsule however the alkylglycerol in higher proportion was octadecenylglycerol (52.4\%) followed by hexadecylglycerol (17\%) and octadecylglycerol (8.4\%) all three giving around $78 \%$.

The tumor-bearing rats supplemented with SLO (WSL) showed $53 \%$ reduction in tumor growth $(\mathrm{p}<0.05 v s . \mathrm{W})$. Exercise caused a reduction of $59 \%$ in the exercised tumor-bearing rats $(\mathrm{p}<0.05 v s$. W). When supplementation was associated with training (EWSL), tumor growth was $47.5 \%$ lower when compared to $\mathrm{W}$ group $(\mathrm{p}<0.05$ vs. $\mathrm{W}$ ) (Table 1). Carcass weight (Body weight after 15 days of tumor-bearing minus tumor weight) of sedentary rats fed regular chow after 15 days tumor-bearing was $13.21 \mathrm{~g}$ lower when compared to the day of tumor inoculation. Supplementation alone (WSL), exercise (EW) and both association (EWSL) were able to avoid carcass weight lost when compared with the day of tumor inoculation $(\mathrm{p}<0.05)$.

The $\mathrm{W}$ group showed hypoglycemia, hyperlactacidemia and hypertriacylglycerolemia featuring a cachetic state (Table 3). SLO supplementation (WSL) and exercise (EW) increased glycemia and decreased lactacidemia and triacylglycerolemia when compared to $\mathrm{W}$ group $(\mathrm{p}<0.05)$. SLO supplementation plus exercise (EWSL) induced additive effect on glycemia, lactacidemia but not in the triacylglycerolemia when compared to WSL and EW $(\mathrm{p}<0.05)$.

The proliferation of Walker 256 tumor cells (Figure 1) obtained from

\begin{tabular}{|l|l|l|l|}
\hline & Tumor-bearing (W) & $\begin{array}{l}\text { Tumor-bearing } \\
\text { Supplemented (WSL) }\end{array}$ & $\begin{array}{l}\text { Tumor-bearing } \\
\text { Exercised (EW) }\end{array}$ \\
\hline Body weight before tumor inoculation (g) & $340.9 \pm 6.40$ & $380.6 \pm 8,05^{\mathrm{a}}$ & $338.3 \pm 6.55$ \\
\hline $\begin{array}{l}\text { Body weight after 15 days of tumor- } \\
\text { bearing (g) }\end{array}$ & $354.1 \pm 7.17$ & $393.5 \pm 8.92^{\mathrm{a}}$ & $352.3 \pm 7.12$ \\
\hline Tumor weight $\mathbf{g})$ & $26.50 \pm 1.79$ & $14.08 \pm 0.91^{\mathrm{a}}$ & $15.60 \pm 0.55^{\mathrm{a}}$ \\
\hline Carcass weight & $327.8 \pm 7.01$ & $379.4 \pm 9.05^{\mathrm{a}}$ & $310.0 \pm 20.51^{\mathrm{ab}}$ \\
\hline Weight change $\mathbf{( g )}$ & $-13.21 \pm 2.25$ & $-2.15 \pm 1.82^{\mathrm{a}}$ & $-1.60 \pm 1.47^{\mathrm{a}}$ \\
\hline
\end{tabular}

Values are means \pm SEM of 10 animals per group. ${ }^{a} p<0.05$ vs. W; ${ }^{b} p<0.05$ vs. WSL e EW

Table 1: Body weight, Tumor weight, and Carcass weight of Walker 256 tumor-bearing rats fed a regular diet (W), supplemented with shark liver oil (WSL), fed regular chow and exercised (EW) and, exercised and shark liver oil supplemented (EWSL). 
Citation: Kryczyk M, Bordignon J, lagher F, Nunes EA, Yamazaki RK, et al. (2014) Exercise and Shark Liver Oil Supplementation Reduce Tumor Growth and Cancer Cachexia in Walker 256 Tumor Bearing Rats. J Cancer Sci Ther 6: 087-093. doi:10.4172/1948-5956.1000254

\begin{tabular}{|l|l|l|}
\hline $\begin{array}{l}\text { Fatty acids } \\
\text { (g/100 g of total fatty acids) }\end{array}$ & $\begin{array}{l}\text { Shark liver oil } \\
\text { Ecomer }\end{array}$ & $\begin{array}{l}\text { Regular chow } \\
\text { Nuvital® (AR-1) }\end{array}$ \\
\hline Lauric acid (12:0) & $1.0 \pm 0.05$ & - \\
\hline Myristic acid (14:0) & $4.8 \pm 0.2$ & - \\
\hline Palmitic acid $(16: 0)$ & $32.6 \pm 2.0$ & $20.7 \pm 3.8$ \\
\hline Palmitoleic acid(16:1n-7) & $6.5 \pm 0.5$ & - \\
\hline Estearic acid (18:0) & $1.6 \pm 0.07$ & $2.3 \pm 0.04$ \\
\hline Oleic acid (18:1n-9) & $28.2 \pm 1.6$ & $19.5 \pm 1.5$ \\
\hline Linoleic acid (18:2n-6) & $1.9 \pm 0.4$ & $51.3 \pm 4.2$ \\
\hline a-Linolenic acid (18:3n-3) & $0.6 \pm 0.08$ & $5.0 \pm 0.2$ \\
\hline Araquidonic acid (20:4n-6) & $0.9 \pm 0.1$ & $0.1 \pm 0.07$ \\
\hline EPA (20:5n-3) & $4.5 \pm 0.3$ & - \\
\hline DHA (22:6n-3) & $12.6 \pm 1.0$ & - \\
\hline
\end{tabular}

Data are presented as mean \pm SEM of 3 independent measurements

Table 2A: Fatty acids profile obtained by HPLC analysis of regular chow provide to all groups and of shark liver oil capsule.

\begin{tabular}{|l|l|}
\hline Alkylglycerol & \% of alkylglycerol \\
\hline Octadecenylglycerol (C18:1) & 50.9 \\
\hline Hexadecylglycerol (C16:0) & 18.0 \\
\hline Octadecylglycerol (C18:0) & 8.1 \\
\hline Heptadecenylglycerol (C17:1) & 1.5 \\
\hline Heptadecylglycerol (C17:0) & 1.2 \\
\hline Others & 20.3 \\
\hline
\end{tabular}

Data are presented as mean \pm SEM of 3 independent measurements

Table 2B: Percentage of alkylglycerol measured in the shark liver oil capsule.

sedentary SLO supplemented (WSL) have a significant reduction of $26 \%$ ( $<<0.05$ vs. W). Tumor cells from exercised group (EW) presented similar reduction of $30 \%(\mathrm{p}<0.05 \mathrm{vs}$. W), but was not different from WSL ( $p>0.05$ ). SLO supplementation plus exercise (EWSL) caused an additive effect upon proliferation reduction ex vivo when compared to WSL and EW $(\mathrm{p}<0.05)$

LP in Walker 256 tumor tissue is shown in the Figure 2. Supplementation with SLO liver oil induced an increase in the lipid peroxidation of $51 \%$ ( $\mathrm{p}<0.05$ vs. W). Exercise also caused an increase of $60 \%$ ( $\mathrm{p}<0.05$ vs. W). The association of supplementation with SLO liver oil and exercise (EWSL) did not cause any further effect ( $p>0.05$ vs. WSL and EW).

Percentage of apoptotic cells detected as annexin- $\mathrm{V}$ positive is represented in the Figure 3. The supplementation with SLO liver oil (WSL) caused an increase by almost 2 -fold in the apoptosis in the tumor cells obtained from supplemented group $(\mathrm{p}<0.001 v s$. W). Exercise also caused an increase in the apoptosis of tumor cells from EW by 2.2 -fold $(\mathrm{p}<0.001 v s . \mathrm{W})$. The association of exercise and SLO liver oil supplementation (EWSL) caused a further increase in the apoptosis of Walker 256 tumor cells by 2.6-fold which was significantly different when compared to W and WSL $(\mathrm{p}<0.05)$.

\section{Bax and Bcl-2 proteins expression}

Bax expression was higher in exercised groups EW and EWSL (Figure 4A). Bcl-2 expression in the WSL, EW and EWSL groups was reduced of 11,25 and $23 \%$, respectively compared to $\mathrm{W}(\mathrm{p}<0.05)$ (Figure $4 \mathrm{~B}$ ). Bax/Bcl-2 ratio (Figure $4 \mathrm{C}$ ) increased only in exercised groups $(\mathrm{EW}$ or EWSL) $(\mathrm{p}<0.05)$

The p65 and p52 expression were reduced in exercised groups (EW and EWSL) $(\mathrm{p}<0.05)$ (Figures $5 \mathrm{~A}$ and $5 \mathrm{~B}$, respectively). The IкB- $\alpha$ expression was higher in groups WSL, EW and EWSL, when compared to $\mathrm{W}(\mathrm{p}<0.05)$ (Figure 5C).

\section{Discussion}

Cachexia is among the most debilitating and life-threatening feature of cancer. Walker 256 tumor-bearing rat offers an opportunity to investigate cancer cachexia and tumor growth due to its characteristics of inducing a higher level of cachexia in only 14 days

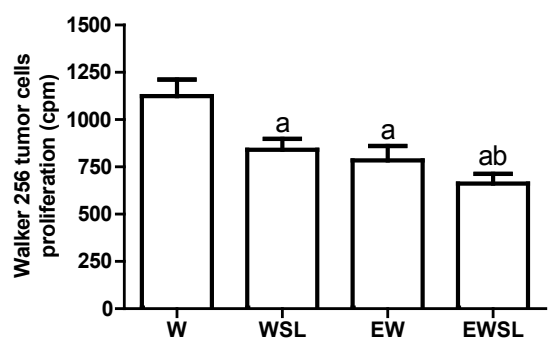

Figure 1: Walker 256 tumor cells proliferation ex vivo in counts per minute (cpm), cells were obtained from sedentary tumor-bearing rats fed a regular chow (W), supplemented orally with shark liver oil (WSL), exercised rats fed regular chow (EW) exercise and supplemented with shark liver oil (EWSL).Data are presented as mean \pm SEM of 20,21, 16 and 19 tumors per group to $W$ WSL, EW and EWSL, respectively. ${ }^{a} p<0.05$ vs. W; ${ }^{b} p<0.05$ vs. WSL e EW.

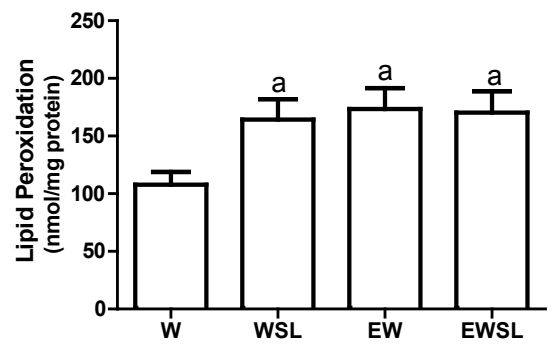

Figure 2: Lipid peroxidation ( $\mathrm{nmol} / \mathrm{mg}$ sample protein content) in tumor samples from tumor-bearing rats fed a control diet (W), supplemented orally with shark liver oil (WSL) and exercised rats fed regular chow (EW), exercise and supplemented with shark liver oil (EWSL). Data are presented as mean \pm SEM of 12 animals per group to W, EW and 15 animals per group to WSL, EWSL. ${ }^{a} p<0.05$ vs. W.

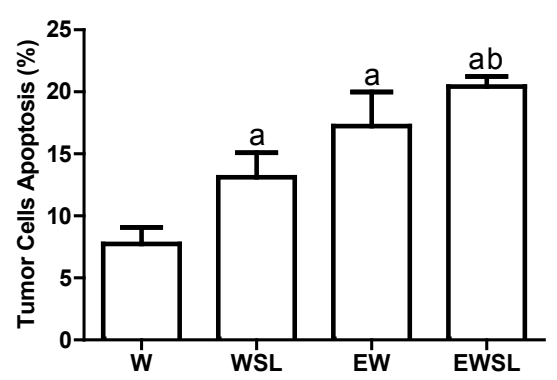

Figure 3: Apoptosis (\%) of Walker 256 tumor cells from tumor-bearing rats fed a regular diet (W), supplemented orally with shark liver oil (WSL), exercised rats fed regular chow (EW), exercise and supplemented with shark liver oil (EWSL). Data are presented as mean \pm SEM of 20, 21, 16 and 19 tumors per group to W, WSL, EW and EWSL, respectively. ${ }^{a} \mathrm{p}<0.05$ vs. $\mathrm{W} ;{ }^{b} \mathrm{p}<0.05$ vs. WSL. 

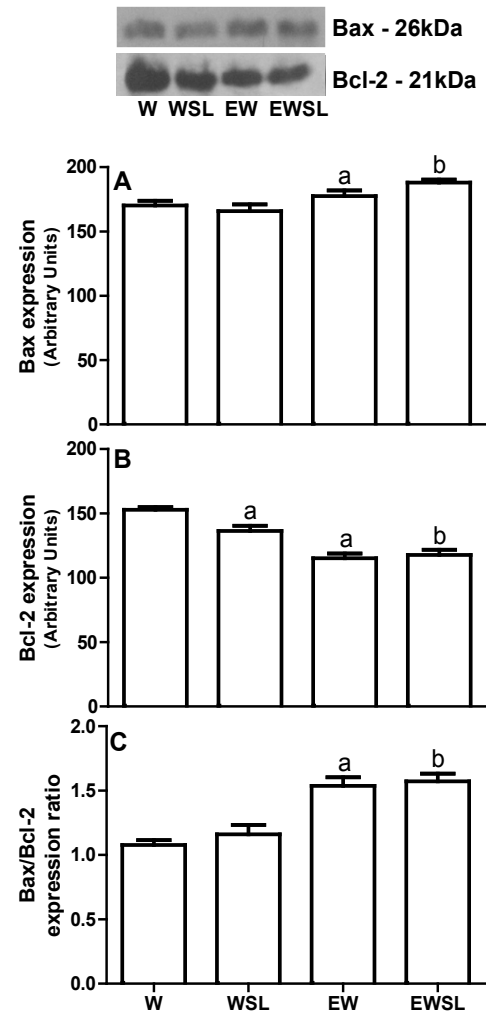

Figure 4: Expression of Bax (A) and Bcl-2 (B) proteins in Walker 256 tumor cells and in tumor-bearing rats fed a control diet $(\mathrm{W})$, supplemented orally with shark liver oil (WSL) exercised rats fed regular chow (EW), exercise and supplemented with shark liver oil (EWSL). Bax/Bcl-2 expression ratio (C). ${ }^{a} p<0.05$ vs. W; ${ }^{p} p<0.05$ vs. WSL.

[1]. A lot of diseases have been linked to lifestyle, diet, smoking and sedentary lifestyle. The practice of regular physical activity and healthy eating habits are significant factors in the prevention and control of some types of diseases even cancer [30]. Here we show for the first time that physical exercise and SLO supplementation combined were able to reduce tumor growth, cachexia development, tumor cells proliferation and increased apoptosis of Walker 256 tumor cells and some of the proteins involved in the mechanism of action.

At the beginning of SLO supplementation until sacrifice rats from WSL group had a significant body weight gain when compared to the other groups (Table 1), around $40 \mathrm{~g}$ higher. Maybe this was caused by lipid intake because exercise balanced such effect. Exercise alone, SLO supplementation and both associated were able to prevent body weight lost (as measured by carcass weight) indicating an anti-cachectic effect. Furthermore, the blood biochemical parameters of cancer cachexia in Walker 256 such as hypoglycemia, triacylglycerolemia and lactacidemia were all restored to normal values [31]. These data show that alone or associated both factors (diet and exercise) have anticachectic properties. The cachectic state aggressiveness might be linked to tumor size and/or tumor cells proliferation ratio. Proliferation of tumor cells was reduced in the WSL, EW and EWSL groups. Which might partially explain the reduction in the proliferation capacity of these cells, as showed before for other tumor cells [32].

Another mechanism by which physical exercise and SLO supplementation can cause reduction of tumor growth seems to involve induction of apoptotic process by increasing lipid peroxidation in tumor tissue and modifying the pattern of expression of proteins linked to induction of cell death [33]. Polyunsaturated fatty acids are more prone to peroxidation than saturated or monounsaturated ones and it is known that peroxidation products may alter cellular membrane structure leading to cell death [34]. The ECOMER ${ }^{\varpi}$ fatty acid profile, quantified by HPLC (Table $2 \mathrm{~A}$ ), showed that $35 \%$ and $21 \%$ of the fatty acids are monounsaturated and polyunsaturated, respectively. This content is in agreement with that obtained by others [35]. Mund et al. [33] have demonstrated that tumor tissue obtained from rats supplemented with fish oil, a rich source of n-3 PUFAs, had a 3 -fold higher degree of lipid peroxidation when compared to those fed regular chow. Increased fatty acid peroxidation is known to produce some deleterious effects, as induction of apoptosis [33]. Our data are in agreement with that, as demonstrated by the increased percentage of apoptotic tumor cells and the reduced expression of the anti-apoptotic protein Bcl-2 in samples harvested from supplemented groups, where lipid peroxidation was increased as well. The liver lipids composition in SLO may change among species, gender, season and other biological factors. Some studies have found small amounts of n-3 fatty acids in SLO of different species, with values around $0.4 \%$ $5.3 \%$ to EPA and $6.5 \%-17.5 \%$ to DHA $[33,35,36]$. Besides n-3 fatty acids, SLO is also rich in alkylglycerols, which can be another source for lipid peroxidation and induce tumor cells apoptosis. In fact we found by GC-MS a high content of alkylglycerol in the capsules offered to the supplemented animals (Table 2B). A study with leukemia patients supplemented with alkylglycerols reported an increased oxidative

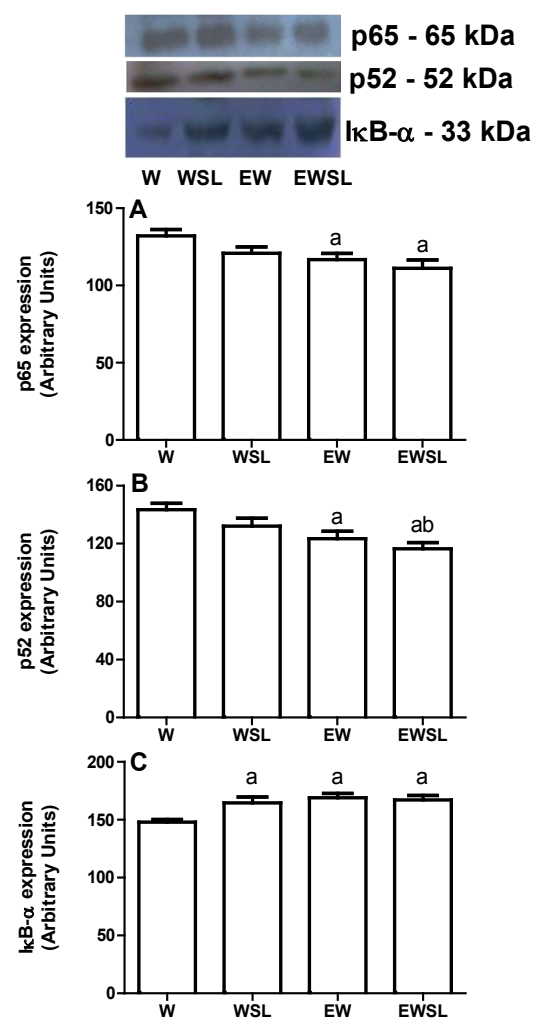

Figure 5: Expression of p65 (A), p52 (B) and IKB- $\alpha$ (C) proteins in Walker 256 tumor cells and in tumor-bearing rats fed a control diet (W), supplemented orally with shark liver oil (WSL) exercised rats fed regular chow (EW), exercise and supplemented with shark liver oil (EWSL). 
Citation: Kryczyk M, Bordignon J, lagher F, Nunes EA, Yamazaki RK, et al. (2014) Exercise and Shark Liver Oil Supplementation Reduce Tumor Growth and Cancer Cachexia in Walker 256 Tumor Bearing Rats. J Cancer Sci Ther 6: 087-093. doi:10.4172/1948-5956.1000254

\begin{tabular}{|l|l|l|l|l|}
\hline & $\begin{array}{l}\text { Tumor-bearing } \\
\text { (W) }\end{array}$ & $\begin{array}{l}\text { Tumor-bearing Supplemented } \\
\text { (WSL) }\end{array}$ & $\begin{array}{l}\text { Tumor-bearing Exercised } \\
\text { (EW) }\end{array}$ & $\begin{array}{l}\text { Tumor-bearing Exercised-Supplemented } \\
\text { (EWSL) }\end{array}$ \\
\hline Serum Glucose (mg/dl) & $68.67 \pm 2.12$ & $76.73 \pm 2.82^{\mathrm{a}}$ & $82.27 \pm 2.64^{\mathrm{a}}$ & $85.42 \pm 2.92^{\mathrm{ab}}$ \\
\hline Serum Lactate $(\mathbf{m m o l} / \mathbf{l})$ & $1.49 \pm 0.06$ & $1.41 \pm 0.05^{\mathrm{a}}$ & $1.30 \pm 0.04^{\mathrm{a}}$ & $1.25 \pm 0.06^{\mathrm{abc}}$ \\
\hline Triacylglycerol $(\mathbf{m g} / \mathbf{d l})$ & $161.40 \pm 9.43$ & $136.60 \pm 11.78^{\mathrm{a}}$ & $130.40 \pm 13.20^{\mathrm{a}}$ & $136.10 \pm 13.00^{\mathrm{a}}$ \\
\hline
\end{tabular}

Abbreviations: $\mathrm{W}=$ tumor-bearing rats fed a regular diet; WSL $=$ supplemented orally with shark liver oil; $E \mathrm{~W}=$ exercised rats fed regular chow; $\mathrm{EWSL}=$ supplemented with shark liver oil. Data are presented as mean \pm SEM of $14,15,12$ and 14 animals per group to W, WSL, EW and EWSL, respectively, for glucose (mg/dl); 10 animals

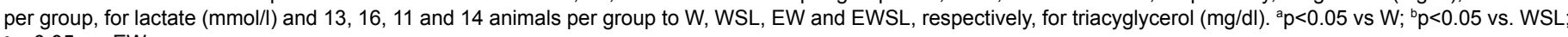
${ }^{c} p<0,05$ vs. EW

Table 3: Serum glucose $(\mathrm{mg} / \mathrm{dl})$, lactate $(\mathrm{mmoL} / \mathrm{l})$ and triacylglycerol $(\mathrm{mg} / \mathrm{dl})$ concentrations in tumor-bearing rats W or WSL and EW or EWSL.

stress after the nutritional intervention, which the authors pointed as the mechanism behind the increased number of apoptotic neoplastic cells in such patients [14].

Physical activity is also able to induce lipid peroxidation in animal and human models [37,38]. Our data corroborate such reports, because we found in the tumor tissues from exercised groups increased lipid peroxidation. The mechanisms by which physical activity-induced lipid peroxidation are not completely understood, but it is well known that during oxidative metabolism much of the oxygen consumed is bound to hydrogen following oxidative phosphorylation, forming water. However, it has been estimated that $4-5 \%$ of the oxygen consumed during respiration is not completely reduced to water, forming free radicals instead. Thus, as oxygen consumption increases during exercise, a concomitant increase occurs in free radical production and lipid peroxidation [38]. Physical exercise has been consistently shown to reduce the risk of some cancers [37], and lipid peroxidation might be one of the possible mechanisms involved in such effect.

Reduced activity of apoptotic pathways is a hallmark of tumor cells [39]. Here we show that exercised groups (EW and EWSL) have an increase in the percentage of apoptotic cells and a pro-apoptotic protein expression environment in the tumor tissue, characterized by increased Bax and decreased Bcl-2 expression. In addition, it is well known that NF- $\mathrm{kB}$ system proteins are involved in tumor cells survival and tumor progression [39]. Decreased expressions of p65 and p52 proteins in tumor cells have been linked to malignancy [40]. Moreover, the increased expression of I $\mathrm{KB}-\alpha$ in tumor cells is usually related to decrements in NF- $\mathrm{KB}$ pathway activation [41]. Our results supported the influences of such protein expression pattern over tumor growth and tumor cells apoptosis. The percentage of apoptotic cells when exercise and supplementation were associated was higher than using both strategies alone. This result suggests that SLO supplementation and physical exercise might be inducing tumor cell death by not completely similar ways, which deserves further investigation.

\section{Conclusions}

In summary, our results suggest that shark liver oil supplementation and exercise alone were able in to avoid the installation of cachexia state and also reduced tumor growth, but the association of both only cause further effect in the tumor growth.

\section{Acknowledgements}

The authors would like to thank the REUNI/CAPES (Foundation for the Coordination of Higher Education Personnel - Brazil) for providing economical support for this research.

There is no conflict of interest for this study.

\section{References}

1. de Lima C, Alves LE, lagher F, Machado AF, Bonatto SJ, et al. (2008) Anaerobic exercise reduces tumor growth, cancer cachexia and increases macrophage and lymphocyte response in Walker 256 tumor-bearing rats. Eur J Appl Physio 104: 957-964.

2. Bacurau AV, Belmonte MA, Navarro F, Moraes MR, Pontes FL Jr, et al. (2007) Effect of a high-intensity exercise training on the metabolism and function of macrophages and lymphocytes of walker 256 tumor bearing rats. Exp Biol Med (Maywood) 232: 1289-1299.

3. Segal RJ, Reid RD, Courneya KS, Malone SC, Parliament MB, et al. (2003) Resistance exercise in men receiving androgen deprivation therapy for prostate cancer. J Clin Oncol 21: 1653-1659.

4. Courneya KS (2003) Exercise in cancer survivors: an overview of research. Med Sci Sports Exerc 35: 1846-1852.

5. Gago-Dominguez M, Jiang X, Castelao JE (2007) Lipid peroxidation, oxidative stress genes and dietary factors in breast cancer protection: a hypothesis. Breast Cancer Res 9: 201.

6. Jenkins RR (2000) Exercise and oxidative stress methodology: a critique. Am J Clin Nutr 72: 670S-4S.

7. Blokhina O, Virolainen E, Fagerstedt KV (2003) Antioxidants, oxidative damage and oxygen deprivation stress: a review. Ann Bot 91 Spec No: 179-194.

8. Cejas P, Casado E, Belda-Iniesta C, De Castro J, Espinosa E, et al. (2004) Implications of oxidative stress and cell membrane lipid peroxidation in human cancer (Spain). Cancer Causes Control 15: 707-719.

9. Salganik RI (2001) The benefits and hazards of antioxidants: controlling apoptosis and other protective mechanisms in cancer patients and the human population. J Am Coll Nutr 20: 464S-472S.

10. Krotkiewski M, Przybyszewska M, Janik P (2003) Cytostatic and cytotoxic effects of alkylglycerols (Ecomer). Med Sci Monit 9: PI131-135.

11. Allgren B, Larsson S (1962) The glycerol ethers in the liver oils of elasmobranch fish. J Lipid Res 1: 1321-1329.

12. Berdel WE, Bausert WR, Weltzien HU, Modolell ML, Widmann KH, et al. (1980) The influence of alkyl-lysophospholipids and lysophospholipid-activated macrophages on the development of metastasis of 3-Lewis lung carcinoma. Eur J Cancer 16: 1199-1204.

13. Wagner BA, Buettner GR, Burns CP (1992) Membrane peroxidative damage enhancement by the ether lipid class of antineoplastic agents. Cancer Res 52 6045-6051.

14. Diomede L, Piovani B, Re F, Principe P, Colotta F, et al. (1994) The induction of apoptosis is a common feature of the cytotoxic action of ether-linked glycerophospholipids in human leukemic cells. Int J Cancer 57: 645-649.

15. Skopinska-Rózewska E, Krotkiewski M, Sommer E, Rogala E, Filewska M, et al. (1999) Inhibitory effect of shark liver oil on cutaneous angiogenesis induced in Balb/c mice by syngeneic sarcoma L-1, human urinary bladder and human kidney tumour cells. Oncol Rep 6: 1341-1344.

16. Voltarelli FA, Gobatto CA, de Mello MA (2002) Determination of anaerobic threshold in rats using the lactate minimum test. Braz J Med Biol Res 35: 13891394.

17. Trinder $P$ (1969) Determination of blood glucose using an oxidase-peroxidase system with a non-carcinogenic chromogen. J Clin Pathol 22: 158-161.

18. Jung DH, Biggs HG, Moorehead WR (1975) Colorimetry of serum cholesterol with use of ferric acetate/uranyl acetate and ferrous sulfate/sulfuric acid reagents. Clin Chem 21: 1526-1530.

19. Engel PC, Jones JB (1978) Causes and elimination of erratic blanks in enzymatic metabolite assays involving the use of NAD+ in alkaline hydrazine 
Citation: Kryczyk M, Bordignon J, lagher F, Nunes EA, Yamazaki RK, et al. (2014) Exercise and Shark Liver Oil Supplementation Reduce Tumor Growth and Cancer Cachexia in Walker 256 Tumor Bearing Rats. J Cancer Sci Ther 6: 087-093. doi:10.4172/1948-5956.1000254

buffers: improved conditions for the assay of L-glutamate, L-lactate, and other metabolites. Anal Biochem 88: 475-484

20. Nunes EA, Kuczera D, Brito GA, Bonatto SJ, Yamazaki RK, et al. (2008) Betahydroxy-beta-methylbutyrate supplementation reduces tumor growth and tumor cell proliferation ex vivo and prevents cachexia in Walker 256 tumor-bearing rats by modifying nuclear factor-kappaB expression. Nutr Res 28: 487-493.

21. Nourooz-Zadeh J, Tajaddini-Sarmadi J, Wolff SP (1994) Measurement of plasma hydroperoxide concentrations by the ferrous oxidation-xylenol orange assay in conjunction with triphenylphosphine. Anal Biochem 220: 403-409.

22. Bradford MM (1976) A rapid and sensitive method for the quantitation of microgram quantities of protein utilizing the principle of protein-dye binding. Anal Biochem 72: 248-254.

23. Folch J, Lees M, Sloane Stanley, GH (1957) A simple method for the isolation and purification of total lipids from animal tissues. J Biol Chem 226 : 497-509.

24. Togni V, Ota CC, Folador A, Júnior OT, Aikawa J, et al. (2003) Cancer cachexia and tumor growth reduction in Walker 256 tumor-bearing rats supplemented with $\mathrm{N}-3$ polyunsaturated fatty acids for one generation. Nutr Cancer 46: 52-58.

25. Naliwaiko K, Araújo RL, da Fonseca RV, Castilho JC, Andreatini R, et al. (2004) Effects of fish oil on the central nervous system: a new potential antidepressant? Nutr Neurosci 7: 91-99.

26. Nishiyama-Naruke A, De Sousa JAA, Carnelós M, Curi R (1998) HPLC Determination of underivatized fatty acid saponified at low temperature analysis of fatty acids in oils and tissues. Anal Lett 31: 2565-2576.

27. Abushufa R, Reed P, Weinkove C (1994) Fatty acids in erythrocytes measured by isocratic HPLC. Clin Chem 40: 1707-1712.

28. Vitorino DC, Buzzachera CF, Curi R, Fernandes LC (2010) Effect of chronic supplementation with shark liver oil on immune responses of exercise-trained rats. Eur J Appl Physiol 108: 1225-1232.

29. Sassaki GL, Souza LM, Serrato RV, Cipriani TR, Gorin PA, et al. (2008) Application of acetate derivatives for gas chromatography-mass spectrometry: novel approaches on carbohydrates, lipids and amino acids analysis. J Chromatogr A 1208: 215-222.
30. Maître C (2009) [Importance of the physical activity in the prevention of the breast cancer]. Bull Cancer 96: 543-551.

31. Pizato N, Bonatto S, Yamazaki RK, Aikawa J, Nogata C, et al. (2005) Ratio of $\mathrm{n} 6$ to $\mathrm{n}-3$ fatty acids in the diet affects tumor growth and cachexia in Walker 256 tumor-bearing rats. Nutr Cancer 53: 194-201.

32. Singh RK, Lokeshwar BL (2009) Depletion of intrinsic expression of Interleukin-8 in prostate cancer cells causes cell cycle arrest, spontaneous apoptosis and increases the efficacy of chemotherapeutic drugs. Mol Cancer 8: 57.

33. Mund RC, Pizato N, Bonatto S, Nunes EA, Vicenzi T, et al. (2007) Decreased tumor growth in Walker 256 tumor-bearing rats chronically supplemented with fish oil involves COX-2 and GE2 reduction associated with apoptosis and increased peroxidation. Prostaglandins Leukot Essent Fatty Acids 76: 113-120.

34. Das UN (1999) Essential fatty acids, lipid peroxidation and apoptosis. Prostaglandins Leukot Essent Fatty Acids 61: 157-163.

35. García E, Gutiérrez S, Nolasco H, Carreón L, Arjona O (2006) Lipid composition of shark liver oil: effects of emulsifying and microencapsulation processes. Eur Food Res Technol 222: 697-701.

36. Jayasinghe C, Gotoh N, Wada S (2003) Variation in lipid classes and fatty acid composition of salmon shark (Lamna ditropis) liver with season and gender. Comp Biochem Physiol B Biochem Mol Biol 134: 287-295.

37. Gago-Dominguez M, Castelao JE, Pike MC, Sevanian A, Haile RW (2005) Role of lipid peroxidation in the epidemiology and prevention of breast cancer. Cancer Epidemiol Biomarkers Prev 14: 2829-2839.

38. Clarkson PM, Thompson HS (2000) Antioxidants: what role do they play in physical activity and health? Am J Clin Nutr 72: 637S-46S.

39. Perkins ND (2004) NF-kappaB: tumor promoter or suppressor? Trends Cell Biol 14: 64-69.

40. Lwin T, Hazlehurst LA, Li Z, Dessureault S, Sotomayor E, et al. (2007) Bone marrow stromal cells prevent apoptosis of lymphoma cells by upregulation of anti-apoptotic proteins associated with activation of NF-kappaB (RelB/p52) in non-Hodgkin's lymphoma cells. Leukemia 21: 1521-1531.

41. Barré B, Perkins ND (2007) A cell cycle regulatory network controlling NFkappaB subunit activity and function. EMBO J 26: 4841-4855. 